

\section{Break-Even Cost for Residential Photovoltaics in the United States: Key Drivers and Sensitivities}

Paul Denholm, Robert M. Margolis, Sean Ong, and Billy Roberts

Prepared under Task No. PVD9.1210

Technical Report NREL/TP-6A2-46909

December 2009

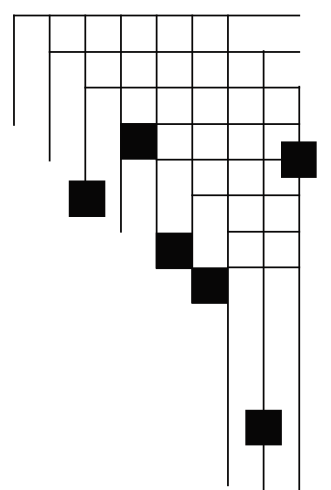




\section{NOTICE}

This report was prepared as an account of work sponsored by an agency of the United States government. Neither the United States government nor any agency thereof, nor any of their employees, makes any warranty, express or implied, or assumes any legal liability or responsibility for the accuracy, completeness, or usefulness of any information, apparatus, product, or process disclosed, or represents that its use would not infringe privately owned rights. Reference herein to any specific commercial product, process, or service by trade name, trademark, manufacturer, or otherwise does not necessarily constitute or imply its endorsement, recommendation, or favoring by the United States government or any agency thereof. The views and opinions of authors expressed herein do not necessarily state or reflect those of the United States government or any agency thereof.

Available electronically at http://www.osti.gov/bridge

Available for a processing fee to U.S. Department of Energy and its contractors, in paper, from:

U.S. Department of Energy

Office of Scientific and Technical Information

P.O. Box 62

Oak Ridge, TN 37831-0062

phone: 865.576 .8401

fax: 865.576 .5728

email: mailto:reports@adonis.osti.gov

Available for sale to the public, in paper, from:

U.S. Department of Commerce

National Technical Information Service

5285 Port Royal Road

Springfield, VA 22161

phone: 800.553.6847

fax: 703.605.6900

email: orders@ntis.fedworld.gov

online ordering: http://www.ntis.gov/ordering.htm 


\section{Acknowledgements}

The authors would like to thank Doug Arent, Justin Baca, Nate Blair, Travis Bradford, Easan Drury, Charlie Hemmeline, and Tom Hoff for helpful comments. 


\section{Executive Summary}

This paper examines the break-even cost for residential rooftop photovoltaic (PV) technology, defined as the point where the cost of PV-generated electricity equals the cost of electricity purchased from the grid. We examine the break-even cost for the largest 1000 utilities in the United States as of late 2008 and early 2009. Currently, the break-even cost of PV in the United States varies by more than a factor of 10 (from less than $\$ 1 /$ Watt to over $\$ 10 /$ Watt) despite a much smaller variation in solar resource. We also consider how the break-costs may change over time, examining a 2015 scenario and the key drivers behind break-even costs. Overall, the key drivers of the break-even cost of $\mathrm{PV}$ are non-technical factors, including the cost of electricity, the rate structure, and the availability of system financing, as opposed to technical parameters such as solar resource or orientation. 


\section{Table of Contents}

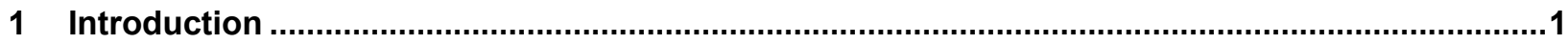

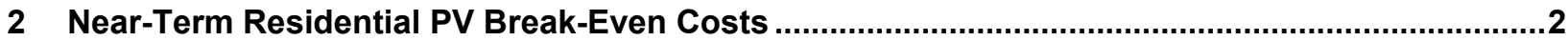

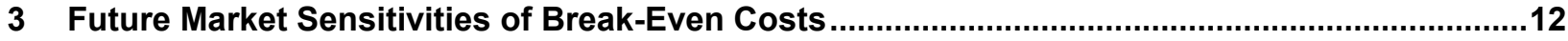

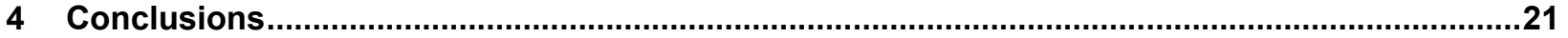

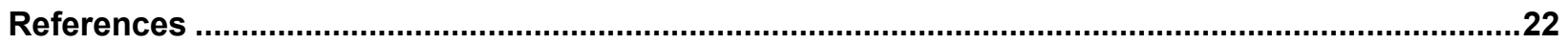

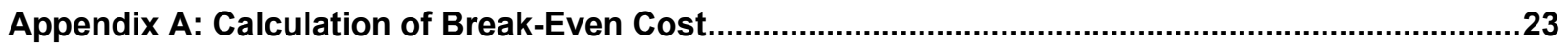

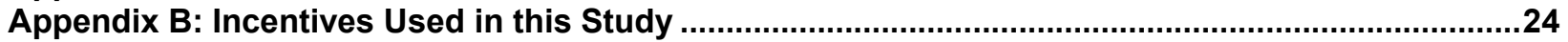

\section{List of Figures}

Figure 1. Residential solar PV break-even cost (\$/W) in 2008 using the most common

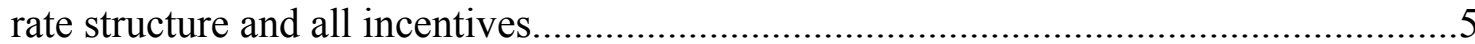

Figure 2. Residential solar PV break-even cost (\$/W) in 2008 using an optional time-ofuse rate structure (where offered) and all incentives ................................................

Figure 3. Components of the break-even value and range in break-even value for each

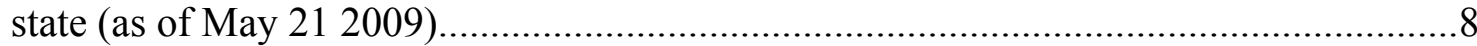

Figure 4. Increase in electricity price required for residential PV breakeven at \$8/W using

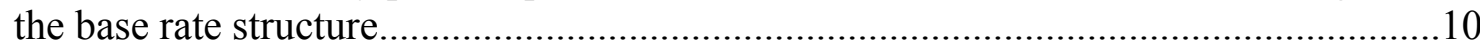

Figure 5. Increase in electricity price required for residential PV breakeven at $\$ 8 / \mathrm{W}$ using an optional time-of-use rate structure where offered ................................................11

Figure 6. Residential solar PV break-even cost (\$/W) in 2015 using the base-case assumptions in Table 1 and the most common rate structure .......................................13

Figure 7. Residential solar PV break-even cost (\$/W) in 2015 using the base-case assumptions in Table 1 and an optional time-of-use rate in all states ....

Figure 8. Increase in electricity price required for residential PV breakeven at $\$ 3.5 / \mathrm{W}$ in 2015 using the base-case assumptions in Table 1 and the most common rate structure.

Figure 9. Increase in electricity price required for residential PV breakeven at $\$ 3.5 / \mathrm{W}$ in 2015 using the base-case assumptions in Table 1 and an optional time-of-use rate in all states.....

Figure 10. Range of PV break-even costs in the 2015 scenarios

\section{List of Tables}

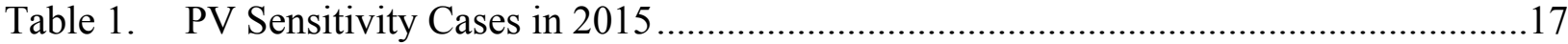

Table A-1. State and Local Incentives Used in this Analysis as of May 21, 2009 ...................24 


\section{Introduction}

The break-even cost for photovoltaic (PV) technology is defined as the point where the cost of PV-generated electricity equals the cost of electricity purchased from the grid. This target has also been referred to as "grid parity" and may be expressed in $\$ / \mathrm{W}^{1}$ of an installed system. Achieving PV breakeven is a function of many variables, including the solar resource, local electricity prices, and various incentives. As a result, for a country like the United States, where these factors vary regionally, there can be considerable variation in break-even cost.

In this report, we provide an updated analysis of PV break-even costs for residential customers in the United States, and we evaluate some of the key drivers of PV breakeven both regionally and over time (commercial buildings will be evaluated in a follow-on report). ${ }^{2}$ We begin by considering a base-case scenario evaluating the break-even cost for residential PV in the largest 1000 utilities in the United States as of late 2008 and early 2009. This base case includes a single set of assumptions for financing, technical performance, and several other factors. We also examine the impact of moving from flat to time-of-use (TOU) rates, and we evaluate the individual components of break-even cost, including effects of rate structure and various incentives. Finally, to examine how residential PV markets might evolve over time and on a regional basis, we examine the break-even requirements in 2015 and consider the sensitivity of the break-even cost to four major drivers: technical performance, financing parameters, electricity prices and rates, and policies.

Currently, the break-even cost of PV in the United States varies by more than a factor of 10 despite a much smaller variation in solar resource. Overall, the key drivers of the break-even cost of PV are non-technical factors, including the cost of electricity, the rate structure, and the availability of system financing, as opposed to technical parameters such as solar resource or orientation. This analysis of the break-even cost of PV represents neither a market depth analysis nor an estimate of likely consumer adoption, but it does provide insight about the potential viability of PV markets.

\footnotetext{
${ }^{1}$ This price refers to $\$ / \mathrm{DC}$ Watt, which is the system's rating before conversion to AC. This nomenclature differs from that generally applied to traditional power plants, which are typically stated in terms of their price per $\mathrm{AC} \mathrm{kW}$ of capacity.

${ }^{2}$ Several previous studies have estimated the break-even cost of PV. These include Herig et al. (2002) and Herig et.al. (2003).
} 


\section{Near-Term Residential PV Break-Even Costs}

We begin with a near-term analysis of residential PV break-even costs using electricity prices as of late 2008 and early 2009 and incentives as of May 2009. We define the break-even cost of PV as the point at which the net present cost (NPC) of the PV system equals the net present benefit (NPB) realized to its owner. This can be used to find the installed system cost $(\$ / \mathrm{W})$ required for a given electricity price $o r$ the price of electricity $(\$ / \mathrm{kWh})$ required for a given installed system cost. A review of the methods used to calculate net present cost and net present benefits is provided in Appendix A.

The break-even cost for PV was calculated for the top 1000 utilities in the United States, which represent about $95 \%$ of the total residential load (based on annual energy consumption). We evaluated both the break-even cost $(\$ / W)$ and the break-even electricity price (cents/kWh). The break-even system cost was calculated by iteratively varying the price of PV until the NPC equaled the NPB. Alternately, the break-even electricity price (cents/kWh) was calculated by iteratively varying the cost of electricity until the NPB equaled the NPC.

The NPC of the system includes all financing and incentives, while the NPB is the cumulative discounted benefits of reduced electric bills. The net present cost in our base scenario assumes a system financed with a home-equity type loan (with tax-deductible interest and a $28 \%$ marginal federal tax rate), a $20 \%$ down payment, a real interest rate and discount rate of $5 \%$, and a loan term of 30 years. ${ }^{3}$ The evaluation period for the analysis was 30 years. ${ }^{4}$

The analysis considered several incentive programs, including the $30 \%$ federal investment tax credit (ITC), as well as known state, local, and utility incentives derived from the DSIRE database. ${ }^{5}$ Tax credits were applied at the end of year 1 in the NPC calculation. ${ }^{6}$ When considering rebates, their taxability and effect on the federal ITC must be considered. In our base assumption, we assume that the rebate is paid to the installer, rather than the homeowner. This effectively reduces the installation price to the

\footnotetext{
${ }^{3}$ Here and elsewhere, we use real interest rates as opposed to nominal interest rates. The relationship is real interest rate $=$ nominal interest rate - inflation rate. To calculate the nominal interest rate, an average inflation rate must be assumed. Our assumption of a 5\% real interest rate is based on the 2008-2009 average home equity loan rate of about $8 \%$ and the average inflation rate of about $3 \%$ during this period. ${ }^{4}$ This implies an expected 30-year life of system.

${ }^{5}$ Database of State Incentives for Renewables and Efficiency (DSIRE), http://www.dsireusa.org/ All incentives as of May 21, 2009

${ }^{6}$ This analysis makes several assumptions that are generally favorable to PV. First, it assumes that PV systems are exempt from sales tax, which is true in some but not all states. In states where PV systems are taxed, the break-even cost would be reduced by a percentage roughly equal to the sales tax rate. Second, the analysis assumes that PV systems are exempt from property tax, which is also true for many but not all regions and states. For a list of states and localities that exempt PV systems from sales and property tax, see DSIRE (http://www.dsireusa.org/).
} 
homeowner by the amount of the rebate, and also reduces the basis for the federal ITC. ${ }^{7}$ A list of the state and local incentives used in this analysis is provided in Appendix B.

When calculating the near-term break-even electricity price (where the PV price is fixed), we assumed a 2008 installed cost of $\$ 8 / \mathrm{W}$ and an inverter replacement at 10 and 20 years. $^{8}$

The NPB at each location was based on the discounted cumulative benefits of reduced electricity bills over the evaluated period, driven by the local PV system performance and electricity rate.

To determine the annual PV generation at each location, we used hourly insolation data for 2003-2005 from the National Solar Radiation Database (NSRDB) (NREL 2007). For each utility, a solar resource location was selected by choosing the location closest to the population-weighted center of the service territory.

Solar insolation values were converted to solar energy production for each of the sites using the PVWATTS/PVFORM model (Marion et al. 2005), assuming a $1 \mathrm{~kW} \mathrm{STC}$ module ${ }^{9}$ and an average system derate factor of $77 \%$ (i.e., including both inverter and other system related efficiency loses). ${ }^{10}$ The base-case assumptions included having a south-facing system with panels tilted at 25 degrees, ${ }^{11}$ and an annual degradation of $0.5 \%$ per year.

Overall, this combination of factors represents a customer who has excellent home orientation and access to attractive financing but places no additional value on locally produced renewable energy. Sensitivities to these assumptions will be evaluated in the next section.

The NPB is highly sensitive to the price of electricity and the electricity rate structure. We evaluated two rate scenarios: one based on the most common (typically flat or seasonally adjusted flat) rate structures and one based on time-of-use (TOU) rate structures. For the most common rate structure scenario, a combination of tariff sheet data and Energy Information Administration (EIA) utility data were used. Form EIA-861

\footnotetext{
${ }^{7}$ The actual treatment of incentives varies depending on their type and source. The primary alterative treatment of incentive taxability occurs when the incentive acts as taxable income but does not decrease the basis for the federal ITC. In reality, with our assumption of a marginal tax rate of $28 \%$, the difference in breakeven price is quite small. We evaluated all 1000 utilities with this alternative approach and found an increase in break-even cost in the range of 1-5\% (with most being in the range of 2-3\%).

${ }^{8}$ Inverter replacements of $\$ 319 / \mathrm{kW}$ in 2018 and $\$ 287 / \mathrm{kW}$ in 2028 are based on estimates from the U.S. Department of Energy (DOE) Solar Energy Technologies Program.

${ }^{9}$ The module efficiency is defined under Standard Test Conditions (STC) of $1,000 \mathrm{~W} / \mathrm{m}^{2}$ solar irradiance and $25^{\circ} \mathrm{C}$.

${ }^{10}$ The derate factor converts the system's DC rating to actual AC output. For additional discussion, see the "DC to AC Derate Factor" discussion of the PVWATTS model at http://rredc.nrel.gov/solar/codes algs/ PVWATTS/version $1 /$ system.html\#derate

${ }^{11}$ Twenty-five degrees corresponds to a roof pitch angle of about $6 / 12$ or roughly midway between the most common roof ranges of $4 / 12$ to $8 / 12$.
} 
data provide the total revenue and total energy sales for all utilities in the United States. ${ }^{12}$ These data were used to form the basis for an "average" cost of electricity to residential customers (equal to the annual residential revenue divided by the annual residential sales). The values provide no insight into the actual rate structure because they average over an entire year and include fixed billing charges and other components that would not be offset by customer-sited PV generation. To establish the relative difference in value between the annual average cost of electricity for each utility and the actual value of PV, we used information from the current tariff sheet for the largest utility in each state. ${ }^{13}$

Using the simulation data from PVWATTS, we multiplied the output of the PV system in each hour by the value of electricity in that hour based on the actual utility tariff (in the flat rate scenario, this value is constant or varies only by season). In this base case, we assume full retail net metering so any electricity exported is worth an amount equivalent to electricity normally consumed (in reality access to full retail net metering is limited, so sensitivities to this assumption are considered in the next section). We developed a simple spreadsheet/Visual Basic for Applications (VBA) tool to calculate the hourly and annual value of PV using different rates; however, publicly and commercially available models can be used for this purpose. ${ }^{14}$

Once we obtained the annual PV value for the largest utility in each state, we compared it to the PV value calculated from the EIA average electricity price data for that utility. The relative difference established a scale factor, accounting for the relative change in value associated with the actual tariff structure as well as removing fixed billing components. ${ }^{15}$ This scale factor was then applied to the remaining utilities in each state. This assumes that the rate structure for the remaining utilities is essentially the same as the largest utility, which is an oversimplification, but it roughly captures the difference in price among utilities in the states. ${ }^{16}$

Future price escalation is also considered to perform the cash-flow calculation. In the base case, we assume that electricity has a real price escalation of $0.5 \% /$ year. ${ }^{17}$

\footnotetext{
${ }^{12}$ Because 2007 was the most recent year available at the time of this report, we scaled each utility to 2008 values using the state average value for 2008 derived from the EIA (2009a).

${ }^{13}$ There is no known single database for all utility tariff sheets. Tariff sheets were gathered from each utility's web site. Because the base tariff sheets often do not include additional costs such as fuel adjustment clauses, the tariff sheets should be read with care. Also, rates from utilities in states that offer customer choice programs may only provide delivery charges with energy costs added separately.

${ }^{14}$ Examples include the Clean Power Estimator at http://www.cleanpower.com/, HOMER at https://analysis.nrel.gov/homer/, and the Solar Advisor Model (SAM) at https://www.nrel.gov/analysis/ $\underline{\operatorname{sam} / .}$.

$\frac{}{15}$ Because EIA revenue data include items such as fixed billing charges, which are not reduced with the installation of PV, most utilities exhibited a lower PV value when using the tariff rates as opposed to using the average rates from EIA's sales and revenue data.

${ }^{16}$ Because of this assumption - and many other assumptions associated with financing, system performance, and other variables - this analysis cannot be used to evaluate any individual system; it represents a general trend in the economics of residential PV.

${ }^{17}$ This is a real price escalation (before the effects of inflation). Estimates of future electricity prices are highly uncertain, and sensitivities to this assumption are provided in the next section. For reference, the
} 
As discussed previously, the break-even point is found by iteratively increasing the cost of the PV system or the cost of electricity until the NPC equals the NPB over the evaluation period.

Figure 1 provides the break-even cost of PV $(\$ / \mathrm{W})$ needed in the "base" rate scenario for the largest 1000 utilities. This scenario uses the most common rate structure, which is generally a flat or seasonal flat rate for most utilities (or an increasing block rate structure for large investor owned utilities in California). ${ }^{18}$ The remaining area in each state (representing the remaining 2173 of 3173 utilities in the EIA data set and providing about $5 \%$ of total U.S. residential electricity sales) uses the PV performance from the largest utility in that state combined with the average electricity price from the smallest utilities in that state. All other assumptions are identical to those of the base case.

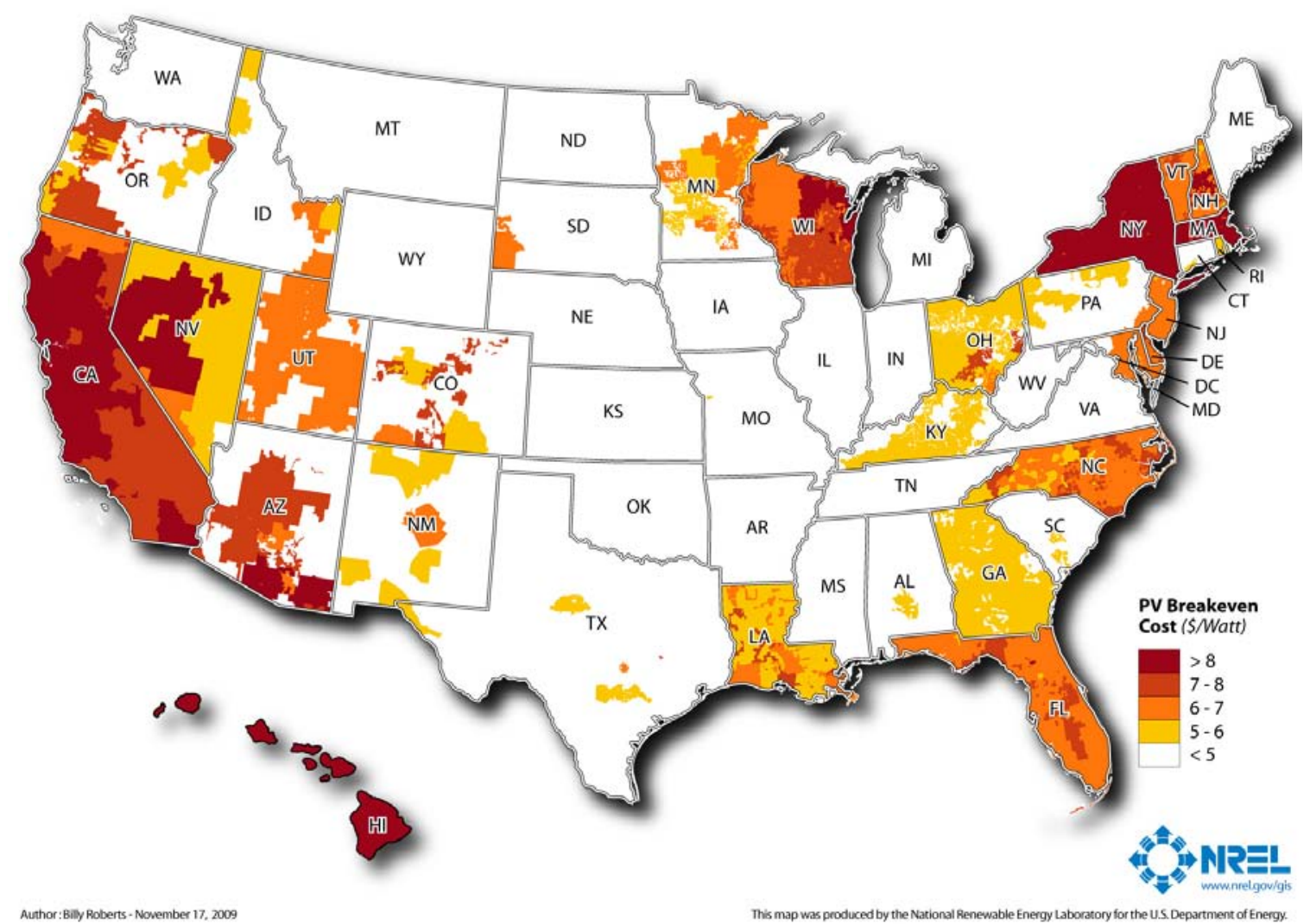

Figure 1. Residential solar PV break-even cost (\$/W) in 2008 using the most common rate structure and all incentives

When considering the results presented in Figure 1 and elsewhere, readers should note that this analysis represents a single point in time (late 2008 and early 2009). Because

EIA's Annual Energy Outlook 2009 (EIA 2009b) projects an annual real increase from 2008 to 2030 of $0.4 \%$.

${ }^{18}$ For California, the base rate structures for investor owned utilities include a tiered-rate schedule with the highest tier exceeding 40 cents $/ \mathrm{kWh}$. Most customers do not consume electricity at the highest tier, and we assumed that PV displaces the second tier. 
incentives and electricity prices are constantly changing, results for any single area may be substantially different when evaluated later. ${ }^{19}$

Figure 1 indicates that the only areas where PV is close to or at breakeven is where there is a combination of high electricity prices and good solar resources (such as California), or a combination of high electricity prices and incentives (such as New York state and Massachusetts). About $11 \%$ of residential electricity sales are in utilities where breakeven conditions exist for the assumptions used in the base case for a PV system cost of $\$ 8 / \mathrm{W}$. At $\$ 6 / \mathrm{W}, 42 \%$ of residential electricity sales are in utilities where some customers may be at breakeven (including customers in states such as Florida, North Carolina, New Jersey, and a growing part of the southwest.) It is important to note that in practice only a fraction of customers in these utility service territories are likely to meet all the criteria (full retail net metering, good solar exposure, and financing) to be at breakeven, and the presence of break-even conditions does not necessarily equate to large consumer adoption. Furthermore, there are budget caps for most current incentive programs and typically limits on the amount of net-metered systems that can be connected to the grid in a specific utility service territory. ${ }^{20}$

This basic methodology used to generate Figure 1 was repeated for the TOU scenario, using the tariff sheets for the largest utility in each state (or region of the state for CA and NY) to estimate the change in PV value associated with TOU rates. Importantly, many utilities, especially smaller utilities, do not offer TOU rates to residential customers. Moreover, even the largest utilities in many states did not offer TOU rates to residential customers at the time of this analysis; overall, we found TOU rates in the largest utility in 25 states and the District of Columbia. In states without TOU rates, the most common rate was evaluated and the break-even cost did not change. In each state where the largest utility offers TOU rates, we assumed that a similar TOU rate structure would be applied to other utilities within that state and that the value of PV would be scaled proportionally across the state. The results of this analysis are shown in Figure 2.

Also noteworthy is that TOU rates do not always result in a net benefit to a customer even when PV has higher value on TOU rates. We found that about $20 \%$ of the TOU rates evaluated showed a decrease in PV value when shifting the customer from a flat rate to a TOU rate. In addition, even with a TOU rate that increases PV value, some customers may opt not to choose TOU rates because their "base" usage would result in increased bills relative to a flat rate. For example, a customer with an above average daytime consumption pattern would likely be worse off switching from a flat rate to a TOU rate. In this analysis, we considered TOU rates in all cases to be optional and we applied only those TOU rates that increase PV value.

\footnotetext{
${ }^{19}$ For example, as of the publication date, a number of state and utility incentive programs for new customers have been modified or eliminated.

${ }^{20}$ As an example, California restricts net metering to $2.5 \%$ of the utility peak demand, while New York and Nevada limit net metering to $1 \%$ of utility peak demand. Incentive limits can be even more restrictive with budgets that are often limited to a very small fraction of a system's total demand. See the Database of State Incentives for Renewables and Efficiency http://www.dsireusa.org/.
} 
Figure 2 provides the results in the same format as Figure 1 but includes optional TOU rate structures where offered.

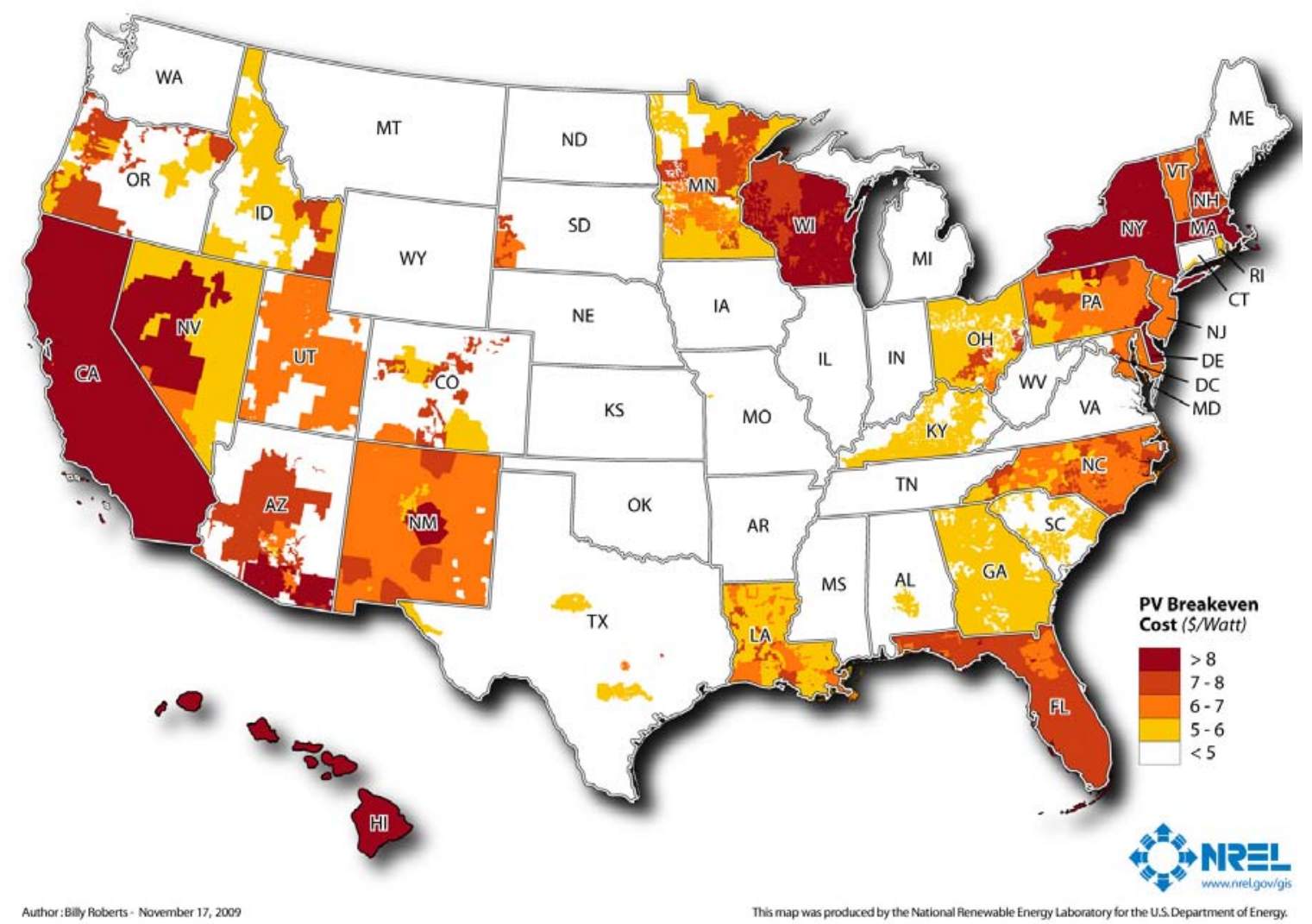

Figure 2. Residential solar PV break-even cost (\$/W) in 2008 using an optional time-of-use rate structure (where offered) and all incentives

The results of this scenario are similar to those in Figure 1 with an increase in break-even price in several states in the Southwest and Northeast plus a few other states such as Wisconsin and Florida. The fraction of sales in utilities where some customers are at breakeven in the TOU scenario increases to $19 \%$ and $45 \%$ for installed costs of $\$ 8 / \mathrm{W}$ and $\$ 6 / \mathrm{W}$ respectively. As noted before, actual adoption will be restricted by consumer adoption behavior and limits on incentives; furthermore, large-scale adoption of PV will change demand and price patterns decreasing the value of PV on TOU rates. ${ }^{21}$

The total break-even cost in each location is the sum of the value of PV from the most common (flat) rate and the additional value derived from incentives and different rate structures. This is illustrated in Figure 3 with the break-even cost for the largest utility in each state along with a distribution of the break-even cost components, including the base electricity rate, the TOU rate "adder" (where available), the effect of the home-equity type loan, and federal and local incentives. Also included is the range in break-even values for the largest 1000 utilities. California and New York were both divided into two

\footnotetext{
${ }^{21}$ At large scale deployment, PV would suppress the mid-day demand for electricity and correspondingly the price. This would act to decrease the value of PV and reduce the likelihood of receiving full-retail net metering. See Denholm and Margolis (2007a) and (2007b) for a discussion of the grid impacts of largescale PV deployment.
} 
sub-regions. California was divided into a Northern and Southern region because of its large size. New York state is split into two regions due to large differences between the New York City/Long Island region (together labeled "NYC") and the remainder of the state (labeled "NY"). The scale is cut off at $\$ 10 / \mathrm{W}$, which is above the 2008 market price of residential PV estimated at an installed cost of about \$8/W (Wiser et al. 2009).

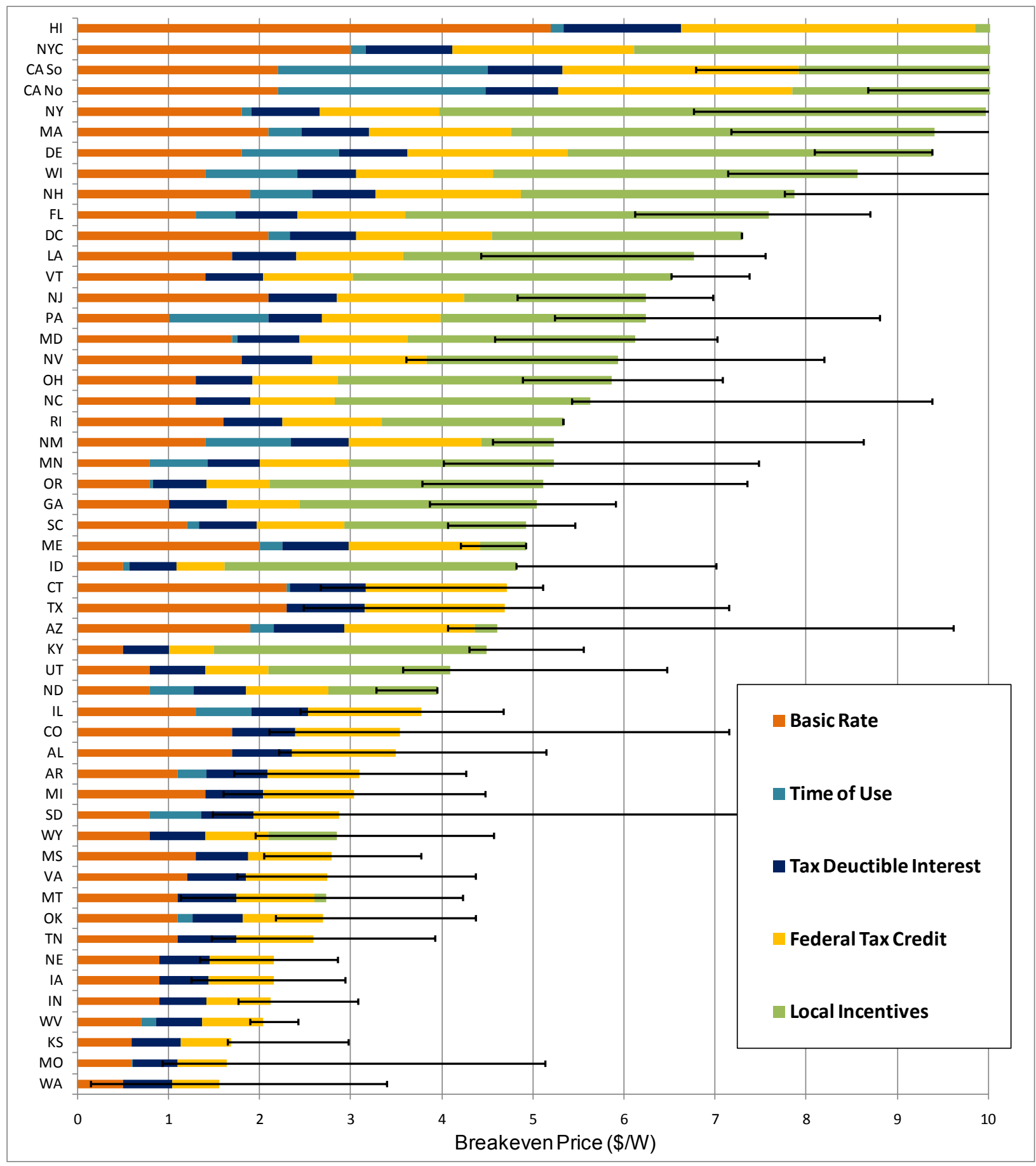

Figure 3. Components of the break-even value and range in break-even value for each state (as of May 21 2009) 
As shown in Figure 3, each state shows considerable variability. In some cases, the break-even value for the most attractive utility is several $\$ / \mathrm{W}$ more than the largest utility. However, these more attractive utilities tend to be significantly smaller than the largest utility, often providing less than a few percent of the state's sales. ${ }^{22} \mathrm{We}$ also see break-even prices above $\$ 4 / \mathrm{W}$ in only a few places without local incentives. In addition, without local incentives or the federal ITC, half of the largest utilities in each state have a break-even cost of under $\$ 2 / \mathrm{W}$. The factors affecting break-even cost are discussed in more detail in section 3 .

Figures 4 and 5 repeat the analysis in Figures 1 and 2 but illustrate the break-even electricity price increase (in cents/kWh) rather than the break-even PV system price (in $\$ / \mathrm{W}$ installed cost). In this case, the price of $\mathrm{PV}$ is assumed to be $\$ 8 / \mathrm{W}^{23}$ and the values on the chart represent the increase in retail electricity price relative to the current price needed for breakeven. Values less than zero represent utilities for which break-even cost was achieved at $\$ 8 / \mathrm{W}$ with the base assumptions. Figure 4 assumes the base rate structure, while Figure 5 provides the results for the TOU rate.

\footnotetext{
${ }^{22}$ As an example, at the time of this analysis the base case breakeven price in the largest utility in New Mexico (serving $50 \%$ of the states residential load) was about $\$ 6.5 / \mathrm{W}$, while the maximum breakeven price in the state was nearly $\$ 10 / \mathrm{W}$. However, this price applies only to a small utility serving about $2 \%$ of the state's residential load.

${ }^{23}$ As mentioned, this analysis was based on prices in late 2008 and early 2009 . As of the publication date, the price of residential PV systems had fallen and prices were as low as $\$ 6 / \mathrm{W}$. However, residential electricity prices had also fallen in some locations.
} 


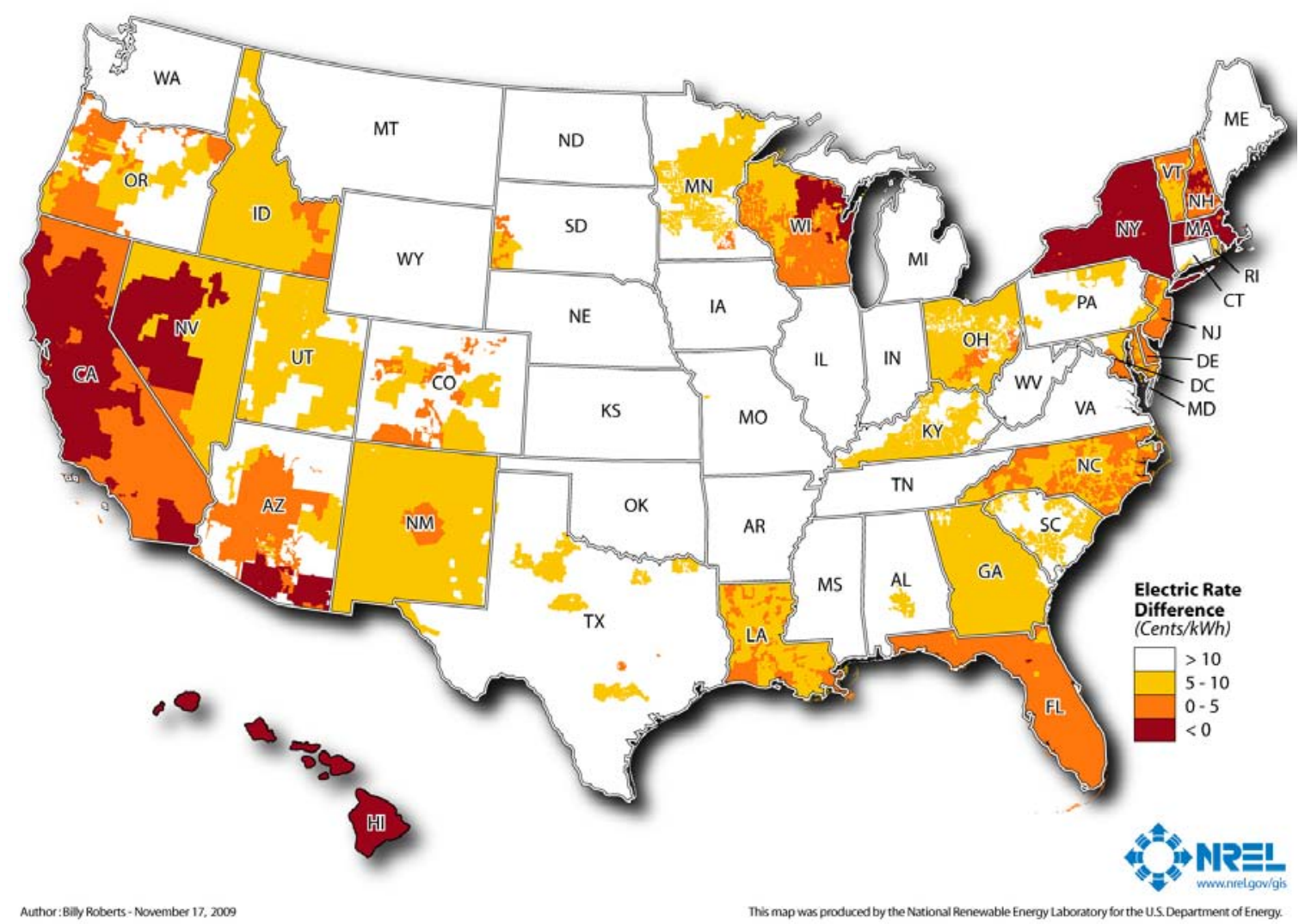

Figure 4. Increase in electricity price required for residential PV breakeven at $\$ 8 / \mathrm{W}$ using the base rate structure

Figure 4 shows the same trends as Figure 1. The areas indicated by a rate difference of less than zero cents $/ \mathrm{kWh}$ are by definition at breakeven and matching the areas in Figure 1 where the break-even price is greater than $\$ 8 / \mathrm{W}$. Figure 4 shows that the price of electricity would have to increase by a significant amount in many parts of the country to achieve break-even conditions, assuming no further decrease in the price of PV. For example, if the price of electricity were to increase 5 cents $/ \mathrm{kWh}$ (from the baseline 2008 values) across the United States, $36 \%$ of residential electricity sales would be in utilities where break-even conditions exist for some customers. Again, note that this is not a depth of market analysis and only a fraction of customers are likely to meet all the criteria for breakeven. 


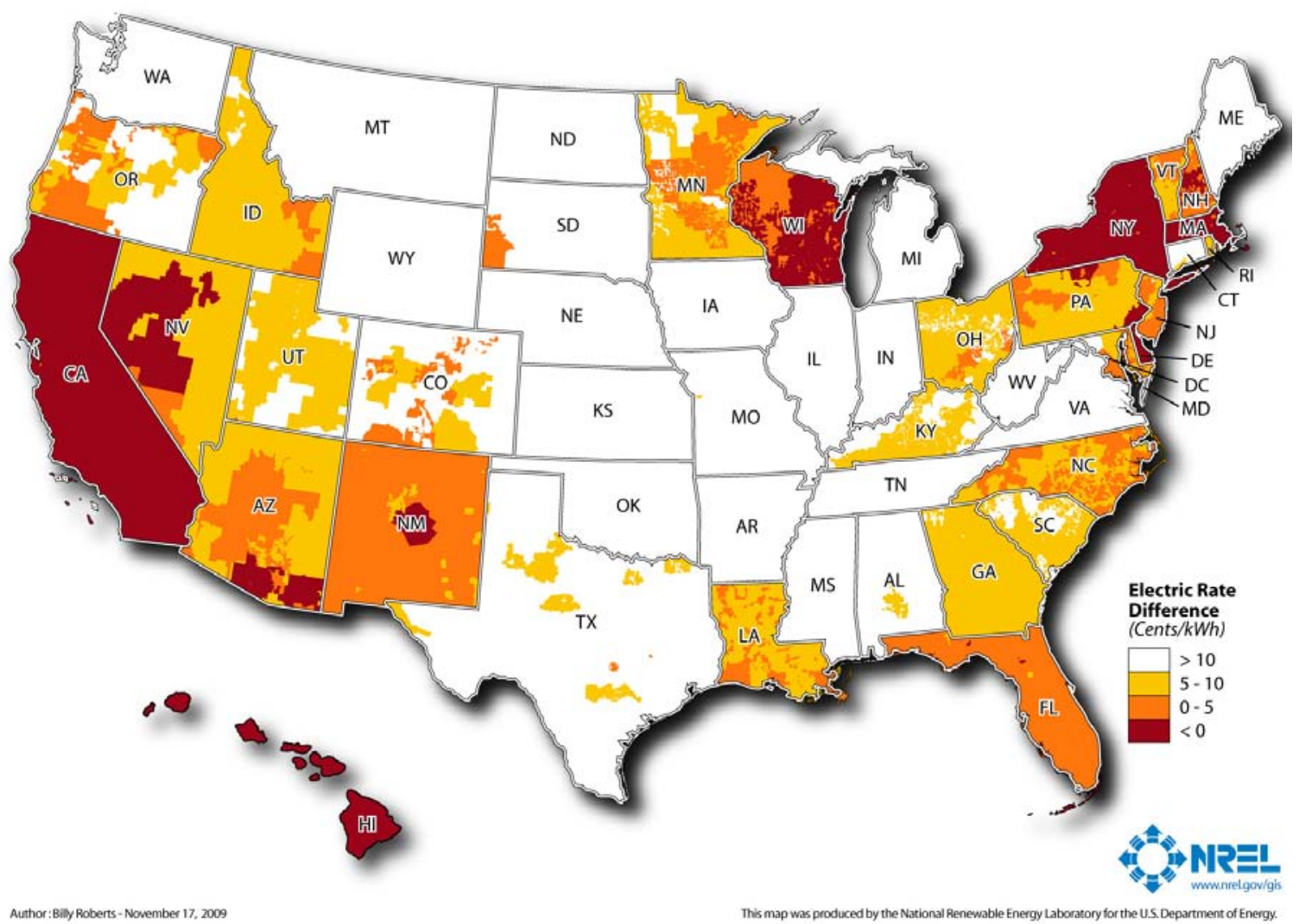

Figure 5. Increase in electricity price required for residential PV breakeven at $\$ 8 / \mathrm{W}$ using an optional time-of-use rate structure where offered

Figure 5 shows the same trends as Figure 2, where the availability of TOU rates in California and several other locations decreases the electricity prices needed to achieve breakeven. 


\section{Future Market Sensitivities of Break-Even Costs}

The high break-even costs in many states that were noted in the previous section are driven primarily by state, utility, and federal incentive programs. These programs are designed primarily to encourage the development of PV markets; however, over time they are expected to be phased down as the cost of PV systems decrease and PV markets become self-sustaining. In this section, we examine the projected break-even cost of residential PV systems in 2015, and we consider the sensitivity of break-even costs to a number of factors.

We begin by establishing a base scenario for 2015 with a uniform set of assumptions, including system performance, electricity price escalation, financing, and incentives. This is similar to the previous scenario but includes an annual real electricity price escalation of $0.5 \%$ that results in an overall increase in electricity prices of 3\% by 2015 . We also eliminate all state incentives ${ }^{24}$ and assume a carbon policy resulting in an effective cost of carbon equal to $\$ 25 /$ ton of $\mathrm{CO}_{2}$. This results in an effective increase in retail electricity prices that is calculated by multiplying the average carbon content of a $\mathrm{kWh}$ of electricity in each state ${ }^{25}$ by the assumed carbon cost. The adders ranged from 0.3 cents $/ \mathrm{kWh}$ in Oregon to 2.5 cents $/ \mathrm{kWh}$ in North Dakota with a national (load weighted) average of $1.5 \mathrm{cents} / \mathrm{kWh}$. Finally, we increased the base derate factor to $82 \%$, representing anticipated improvement in inverters and other balance of system components. We then calculated the break-even cost in each of the largest 1000 utilities for this base scenario.

Figures 6-9 provide the results for the 2015 base case beginning with the break-even price for PV using the most common rate. In Figures 6 and 7, the scale has been modified from Figure 1 with a maximum $\mathrm{PV}$ cost of $\$ 6 / \mathrm{W}$ to reflect the expected reduction in cost.

\footnotetext{
${ }^{24}$ We keep the federal ITC at 30\% since it does not expire until the end of 2016. (See http://www.dsireusa.org/). However we consider elimination of the federal tax credit as sensitivity.

${ }^{25}$ These values are based on the average emissions factors from Energy Information Administration (2002). For a discussion of average versus marginal avoided emissions rates, see Rothschild \& Diem (2009)
} 


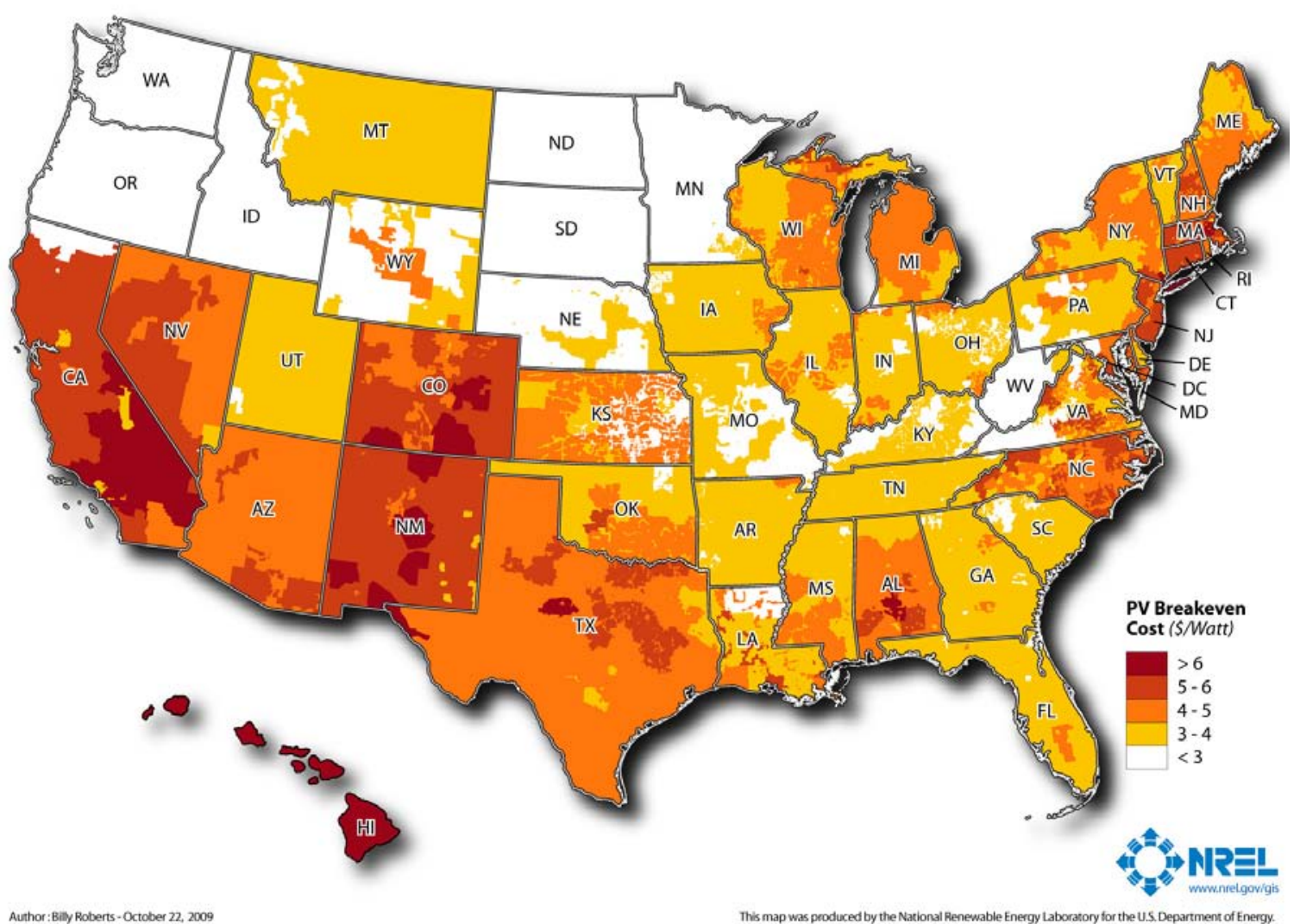

Figure 6. Residential solar PV break-even cost (\$/W) in 2015 using the base-case assumptions in Table 1 and the most common rate structure

The 2015 case shows a dramatic reduction in the break-even cost of PV where local incentives existed in early 2009. Alternatively, in locations where no incentives existed in early 2009 , the assumed electricity price escalation increases the break-even price. In this case, $43 \%$ of residential electricity sales are in utilities where break-even conditions occur for some customers when PV system costs $\$ 4 / \mathrm{W}$. At $\$ 3 / \mathrm{W}, 85 \%$ of residential electricity sales are in utilities where some customers are at break-even cost. ${ }^{26}$

Figure 7 repeats the analysis for a time-of-use rate structure but with an additional difference between this case and the 2009 case (Figure 2). In the 2009 case, we considered only states where the major utilities offer TOU rates to residential customers. In the 2015 case, we assumed that all utilities offer TOU rates; in states that do not currently offer TOU rates, we used the TOU multiplier from a nearby state. As in the 2009 case, this multiplier was applied to all utilities in the state. The result is a significant shift in the break-even cost in many states. Here, the $\$ 4 / \mathrm{W}$ and $\$ 3 / \mathrm{W}$ percentages are $75 \%$ and $91 \%$ respectively.

\footnotetext{
${ }^{26}$ Since these figures are percentages, they would not change with absolute population growth. However, they assume neither demographic shifts (equal population growth in all states) nor changes in electricity usage patterns.
} 


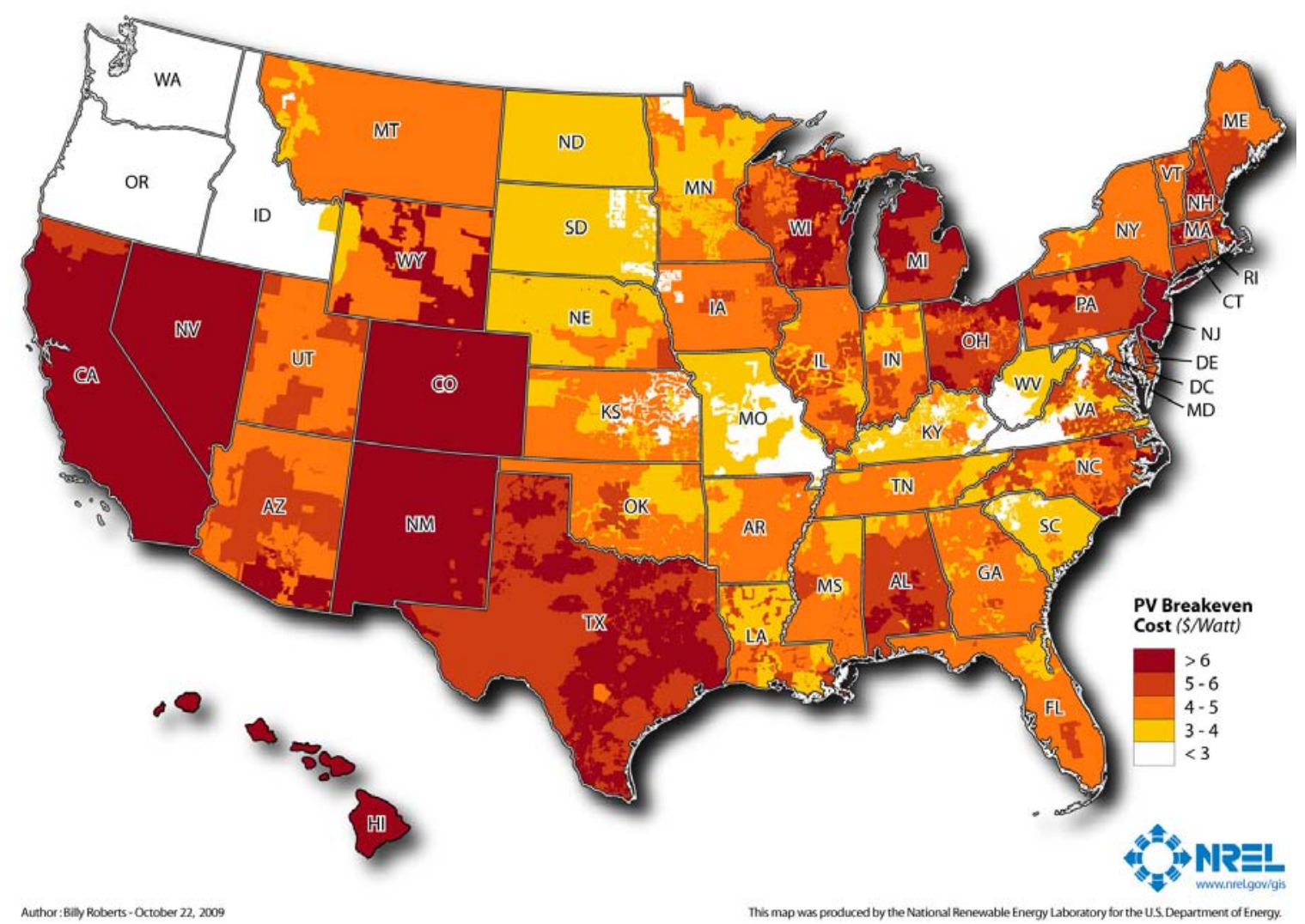

Figure 7. Residential solar PV break-even cost (\$/W) in 2015 using the base-case assumptions in Table 1 and an optional time-of-use rate in all states

Figures 8 and 9 show the electricity price difference for the 2015 base case. In this scenario, we assume a base installed cost of $\$ 3.5 / \mathrm{W}$, which is the current target for the U.S. Department of Energy's Solar Energy Technologies Program (U.S. DOE 2008). 


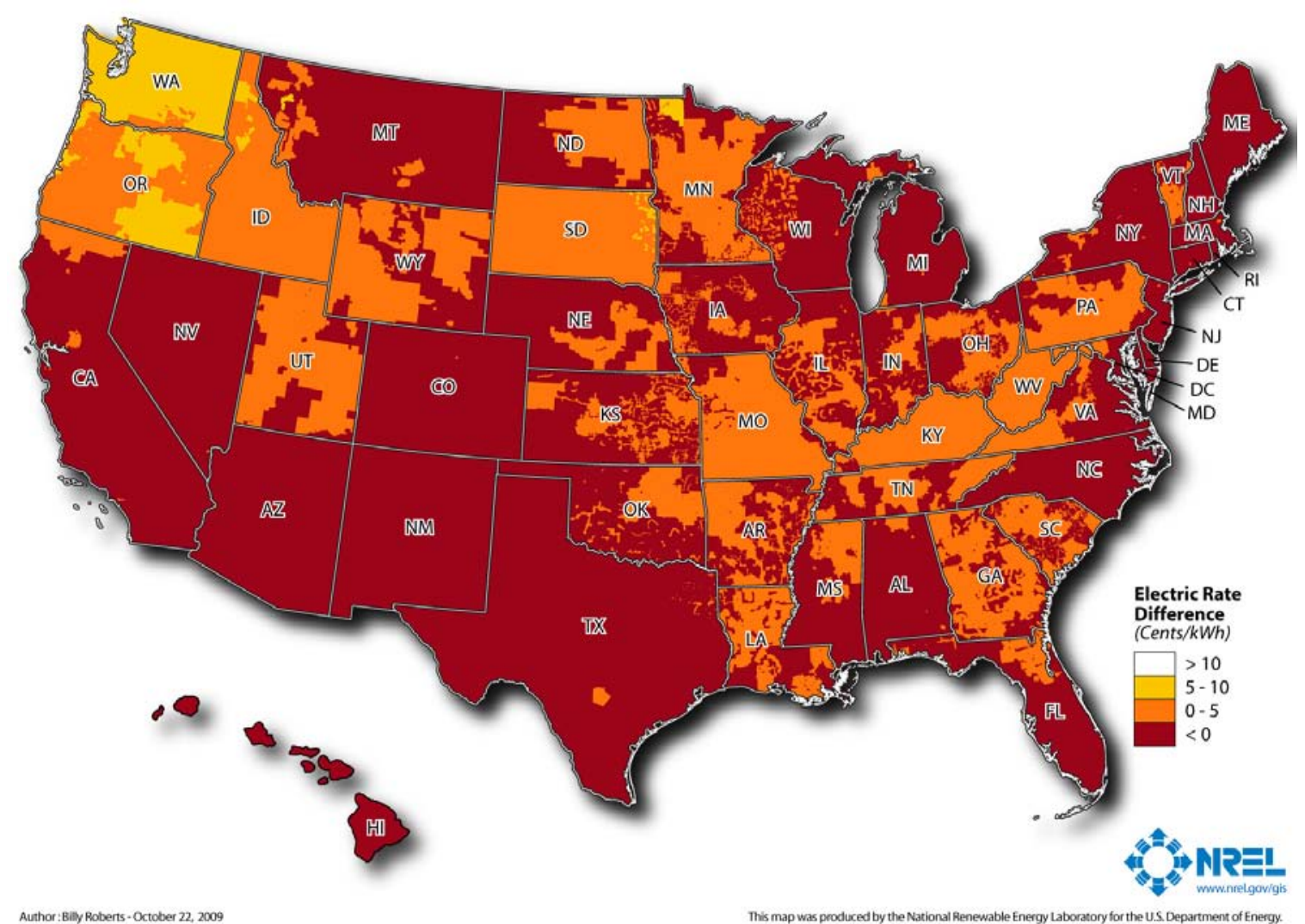

Figure 8. Increase in electricity price required for residential PV breakeven at $\$ 3.5 / \mathrm{W}$ in 2015 using the base-case assumptions in Table 1 and the most common rate structure

As illustrated in Figure 8, if the Solar Program's PV cost targets are met by 2015, breakeven conditions will exist for some customers in most of the Southwest and New England, representing $67 \%$ of U.S. residential electricity sales. However, the base-case assumptions notably include a continuation of the $30 \%$ federal ITC $^{27}$ and a $\$ 25 /$ ton carbon cost and do not consider actual consumer adoption behavior under these conditions.

\footnotetext{
${ }^{27}$ The federal ITC, as extended in 2008, is set to expire on December 31, 2016. See http://www.dsireusa.org/.
} 


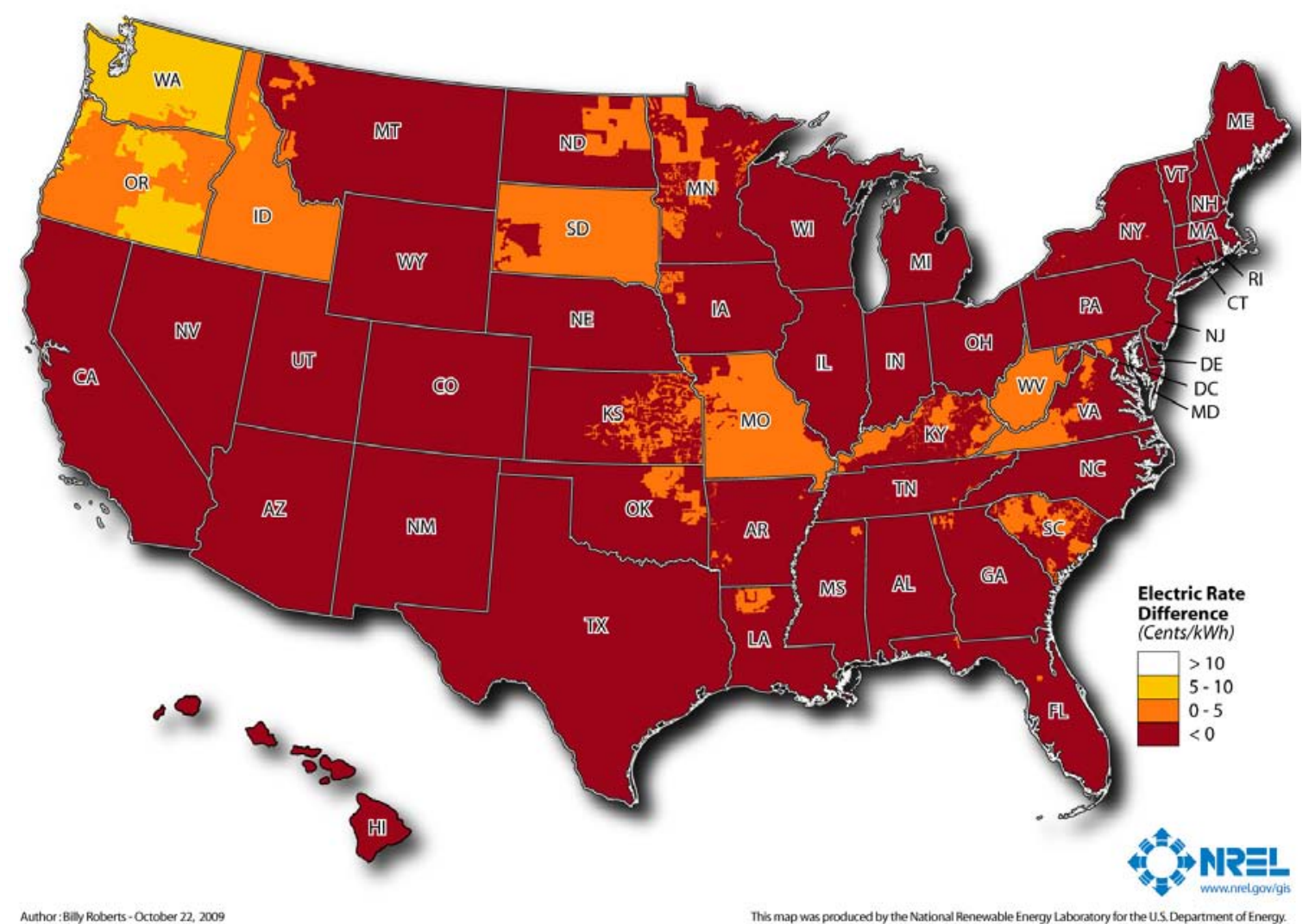

Figure 9. Increase in electricity price required for residential PV breakeven at $\$ 3.5 / \mathrm{W}$ in 2015 using the base-case assumptions in Table 1 and an optional time-of-use rate in all states

Moving to universally available and optional TOU rates (with full retail net metering) increases to $88 \%$ the fraction of sales where break-even conditions exist. However, the base 2015 scenarios represent only a single scenario among many possible scenarios for future break-even costs. The PV market of the future will have a variety of customers with different financing options, homes with non-optimal orientations, and changes in electricity prices and rates. Many of these drivers, such as escalation of electricity prices and carbon policies, are highly uncertain. As a result, it is important to consider the sensitivity of the break-even price to a variety of drivers.

We examined the sensitivity of the break-even cost for each state to a set of four classes of impacts: technical performance, electricity cost, financing, and policies. Table 1 lists the base case and the four sensitivity cases evaluated. 
Table 1. PV Sensitivity Cases in $2015^{a}$

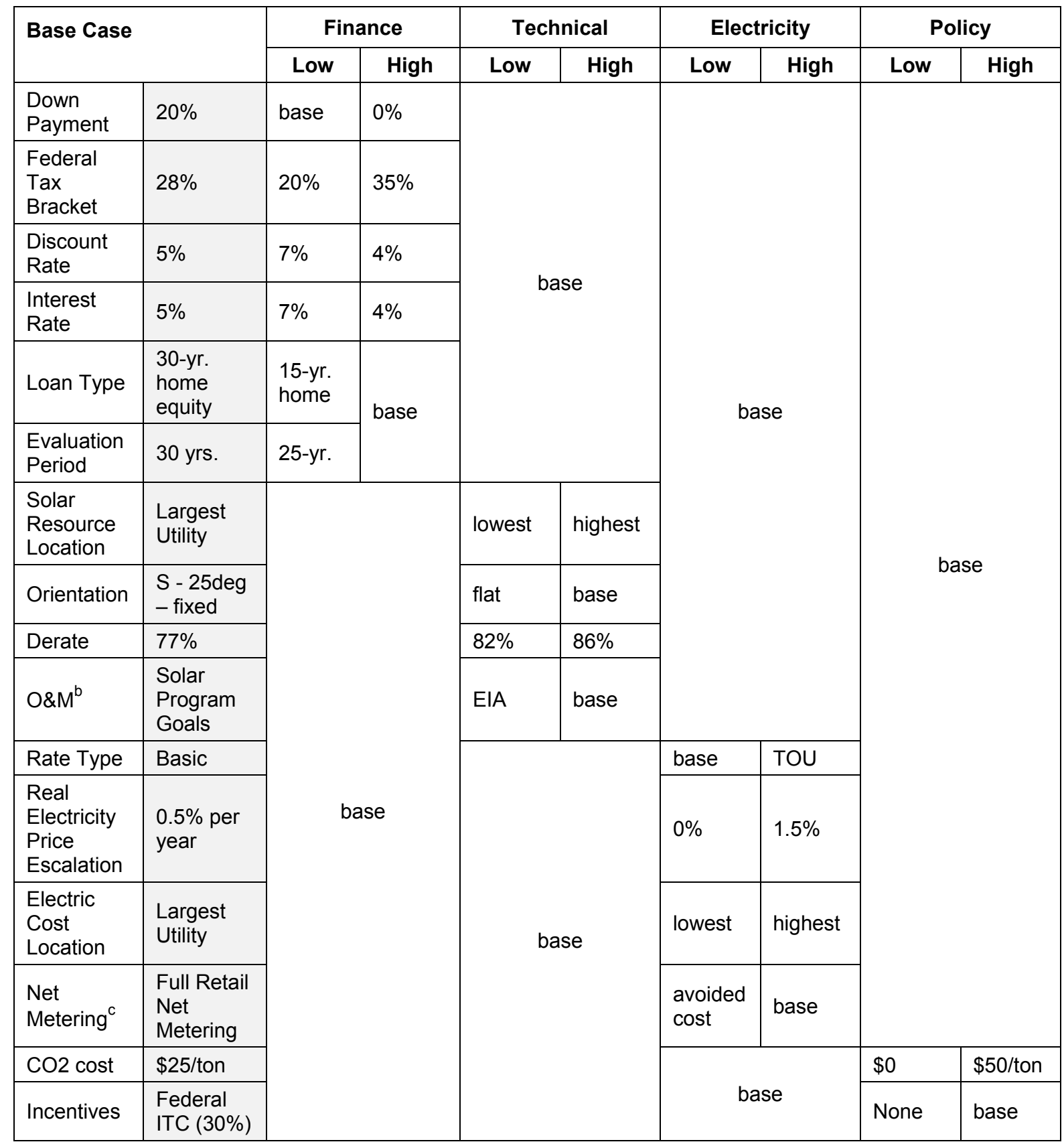

${ }^{\mathrm{a}}$ The values used in Table 1 are not intended to represent all possible scenarios but were chosen to provide a reasonable range of values for each parameter. ${ }^{b} \mathrm{O} \& \mathrm{M}$ values were based on inverter replacements at 10 and 20 years (2025 and 2035). Solar program goals (base case) assumed $\$ 297 / \mathrm{kW}$ in 2025 and $\$ 280 / \mathrm{kW}$ in 2030 . EIA values used were $\$ 974 / \mathrm{kW}$ and $\$ 960 / \mathrm{kW}$ for 2025 and 2030 respectively.

${ }^{\mathrm{c}}$ Avoided cost assumes that PV (1) offsets only the fuel cost of a mix of combined-cycle and single cycle gas turbines with a composite heat rate of $8000 \mathrm{BTU} / \mathrm{kWh}$ and (2) receives no credit for capacity or T\&D losses. For further discussion of avoided fuels, see Denholm et al. (2009).We used the projected natural gas price in 2015 from the 2009 Annual Energy Outlook (EIA 2009), which results in a national average avoided cost of 5.4 cents $/ \mathrm{kWh}$. 
Figures 10a and 10b provide the results. In each state, a base-case break-even cost based on the largest utility in the region is provided; four error bars show the range of breakeven costs for the sensitivity cases. Each of the four drivers has a low case and a high case. The low case, which decreases the economic performance of PV and moves the error bar left, represents a lower break-even cost. Examples include lower PV output from non-optimal orientation or a premature elimination of the federal ITC. The low cases could also represent the impact of reducing the benefits of TOU rates or retail net metering. The high case represents improved economy performance, increasing the break-even price. Examples include a higher derate factor (perhaps resulting from improved inverter efficiency) or a larger effective cost of carbon.

The scenarios and error bars in the figures are partially additive. For example, both a more aggressive carbon policy and improved derate factors could occur, decreasing the break-even cost more than these factors individually. However, these factors are not completely additive; for example, the highest solar resource location in each state may not correspond to the highest price region. 


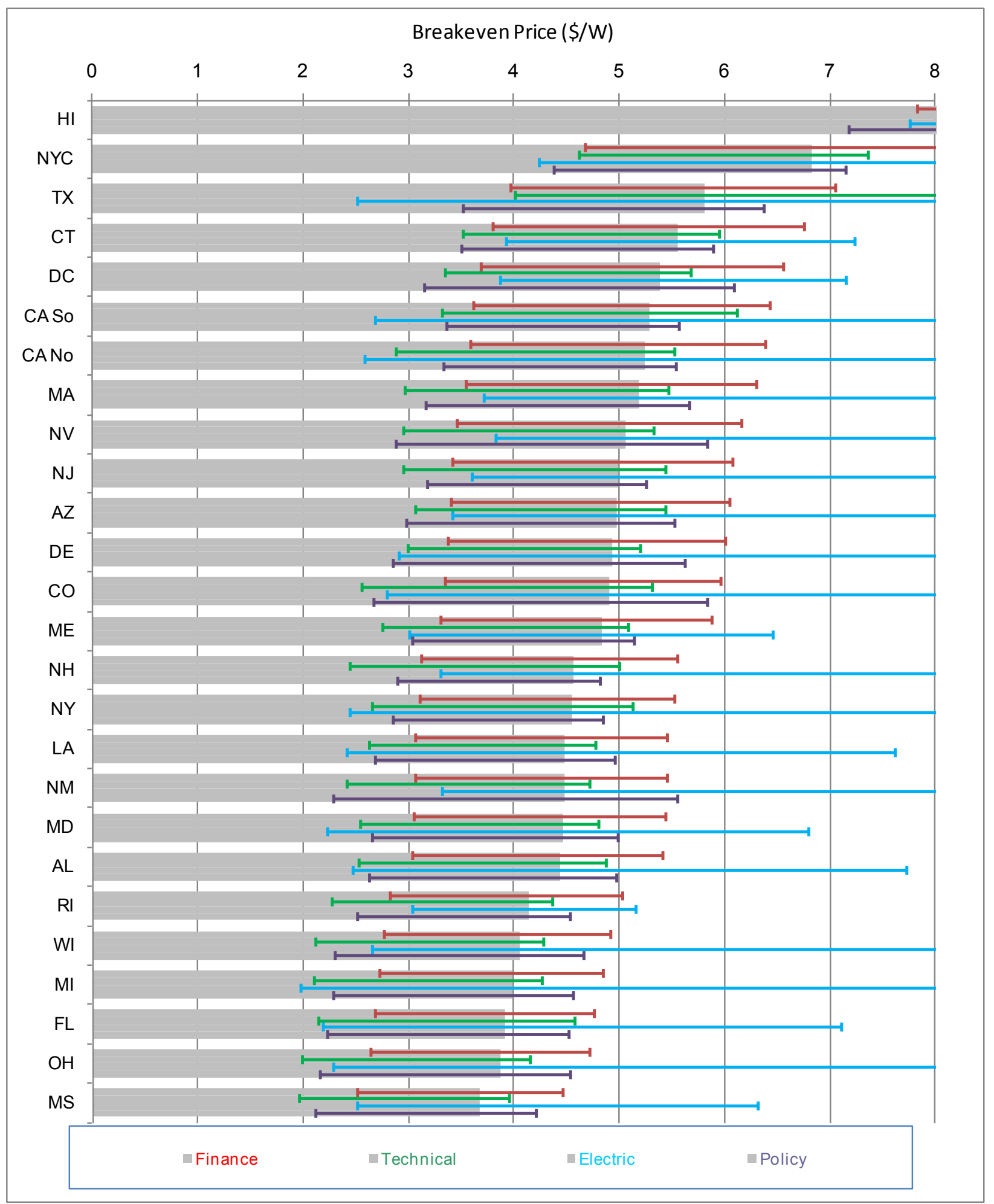

Figure 10a. Range of PV break-even costs in the 2015 scenarios: Top 26 regions 


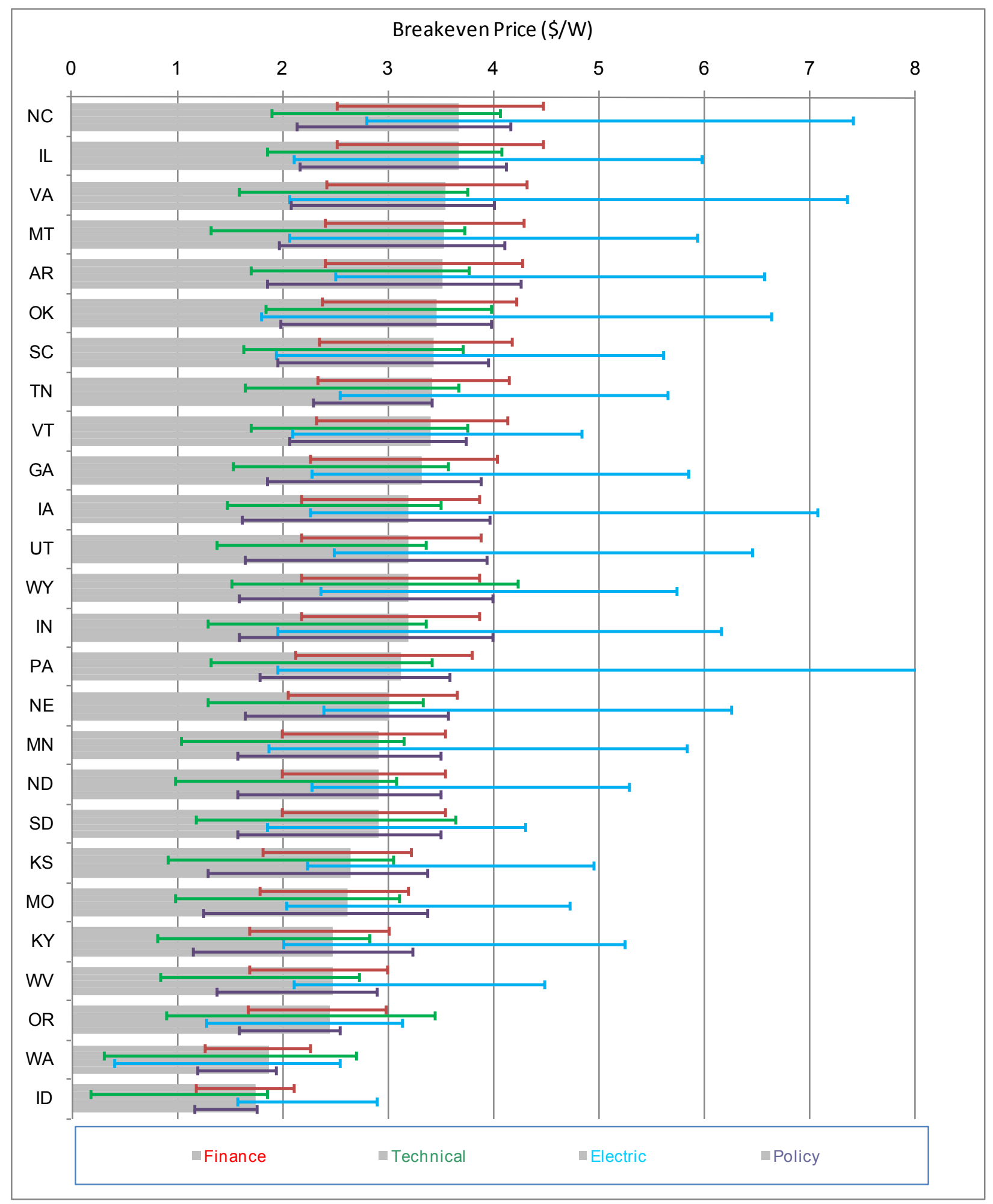

Figure 10b. Range of PV break-even costs in the 2015 scenarios: Bottom 26 regions 
As shown in Figure 10, the base-case break-even price in 2015 is between $\$ 1.6 / \mathrm{W}$ and $\$ 6.2 / \mathrm{W}$ (excluding Hawaii). Figure 10 shows that the electricity price is the biggest driver of break-even price variation and is followed generally by finance factors, policy issues, and technical performance. The variation in the electricity prices is due more to the spread between utilities within a state than the variation in the price escalation assumed. The finance assumptions result in a roughly symmetrical impact on breakeven of $+/-35 \%$ across all states. The ITC is the single largest policy driver evaluated. Technical sensitivities are the least important variable and generally decrease the breakeven price because of the analysis of the flat orientation case, which reduces the annual average PV output by about $13 \%$.

Each of the four impact categories reported in Figure 10 combines several drivers, obscuring the contribution from each. For example, the breakeven cost is highly sensitive to the derate factor on a percentage basis, but the derate factor can only increase by a relatively small amount. Alternatively, several finance and policy drivers such as interest rate or $\mathrm{CO}_{2}$ cost can have a much larger range, which increases the range of breakeven costs that is due to these factors. A follow-on report will examine these sensitivities in more detail, including the impact of individual parameters as well as the likely range of these parameters.

\section{Conclusions}

We evaluated the break-even price for residential PV customers in the United States and found that the current break-even price varies by more than a factor of 10 even though the solar resource varies by less than a factor of two. This difference is largely driven by incentives, which can exceed $\$ 5 / \mathrm{W}$, and the difference in electricity prices, which can vary by a factor of eight (or more when considering the range of tiered rates in California). Even without incentives, large variations in break-even cost will remain given the range of financing options and other non-technical factors.

The general trend observed in this analysis is that break-even conditions appear first in the Southwest where they are driven by resource and in the Northeast where they are driven by high electricity prices. As PV system prices continue to decline, break-even conditions begin to occur in the Southeast and Midwest. Very low electricity prices will preclude break-even conditions in certain areas in the Northwest and Midwest even with $\mathrm{PV}$ prices at $\$ 3.5 / \mathrm{W}$ and continuation of the federal investment tax credit.

Overall, the scenarios evaluated represent a market entry point for solar PV. However, the scenarios do not consider the potential for a deep, sustained market. Therefore, caution must be used when considering this analysis. PV breakeven does not imply that customers will necessarily adopt PV, and only a fraction of customers in each utility will have the necessary combination of good solar access and attractive financing options. A true depth of market analysis is required to determine a "demand curve" for PV at various price points. This must be combined with analysis of commercial buildings to provide an estimate for the market potential of rooftop PV. 


\section{References}

Denholm, P.; Margolis. R. M. (2007a). "Evaluating the Limits of Solar Photovoltaics (PV) in Traditional Electric Power Systems." Energy Policy (35); pp. 2852-2861.

Denholm, P.; Margolis. R. M. (2007b) "Evaluating the Limits of Solar Photovoltaics $(\mathrm{PV})$ in Electric Power Systems Utilizing Energy Storage and Other Enabling Technologies." Energy Policy (35); pp. 4424-4433.

Denholm, P.; Margolis, R. M.; Milford, J. (2009). "Quantifying Avoided Fuel Use and Emissions from Photovoltaic Generation in the Western United States" Environmental Science and Technology (43); pp. 226-232.

Energy Information Administration (March 2002). Updated State-and Regional-level Greenhouse Gas Emission Factors for Electricity.

EIA (2009a). Electric Power Monthly: May 2009. DOE/EIA-0226 (2009/05).

Washington, DC: Energy Information Administration.

EIA (2009b). Annual Energy Outlook 2009: With Projections to 2030. DOE/EIA0383(2009). Washington, DC: Energy Information Administration.

Herig, C. ; Gouchoe, S.; Haynes, R; Perez, R.; Hoff T. (2002). "Customer Sited PV: A State Market Analysis." Proc. ASES Annual Meeting, Reno NV.

Herig, C.; Gouchoe, S.; Perez, R.; Hoff, T. (2003). "PV in Commercial Buildings Mapping the Breakeven Turn-Key Value of State Markets." Proc. ASES Annual Meeting, Austin, TX.

Marion, B.; Anderberg, M.; Gray-Hann, P. (2005). Recent Revisions to PVWATTS. NREL/CP-520-38975. Golden, CO: National Renewable Energy Laboratory.

National Renewable Energy Laboratory (NREL). (2007). National Solar Radiation Database 1991-2005 Update: User's Manual. NREL/TP-581-41364. Golden, CO: National Renewable Energy Laboratory.

Rothschild S.; Diem, A. (2009). "Total, Non-baseload, eGRID Subregion, State? Guidance on the Use of eGRID Output Emission Rates." 18th International Emission Inventory Conference, Baltimore, Maryland.

Wiser, R.; Barbose, G.; Peterman, C.; Darghouth, N. (2009). Tracking the Sun II: The Installed Cost of Photovoltaics in the U.S. from 1998-2007. LBNL-2674E. Berkeley, CA: Lawrence Berkeley National Laboratory.

U.S. Department of Energy (2008). Solar Energy Technologies Program. Multi Year Program Plan 2008-2012. Washington, DC: U.S. DOE. 


\section{Appendix A: Calculation of Break-Even Cost}

The break-even cost of a PV system is defined as the point where the net present cost (NPC) of the system equals the net present benefit (NPB) to its owner.

The NPC is the cumulative discounted cost of the system, including initial cost, financing, tax impacts, incentives, and operation and maintenance (O\&M), equal to the sum of the cost in each year multiplied by the discount factor in that year.

The discount factor in year $y=\frac{1}{(1+d)^{y}}$

where $d$ is the discount rate.

The cost in each year is based on the system financing. At the beginning of the financing period, a down payment and then a loan amount are established by:

Loan Amount $=$ PV System cost - Down payment - Initial Rebates

The annual loan payment is then calculated by:

$$
\text { Loan Payment }=\text { Loan Amount } * \frac{i(1+i)^{n}}{(1+i)^{n}-1}
$$

where $i$ is the interest rate and $n$ is the loan term in years. The tax savings on the loan interest in each year $y$ is given by:

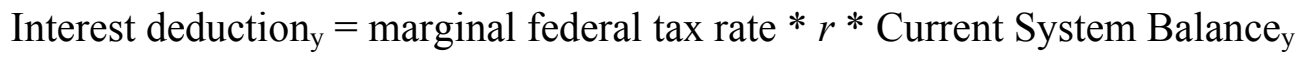

Some incentives (such as tax incentives) may not occur until a year or so after installation. These incentives are discounted by one year.

The NPB is the discounted cumulative benefits of reduced electricity bills over the evaluated period or the sum of the benefits in each year multiplied by the discount factor. 


\section{Appendix B: Incentives Used in this Study}

Table A-1. State and Local Incentives Used in this Analysis as of May 21, 2009

\begin{tabular}{|c|c|c|c|c|}
\hline State/Utility & Buydown & $\begin{array}{c}\text { Tax } \\
\text { Incentive }\end{array}$ & Other & Total \\
\hline$A Z$ & & $\$ 0.25$ & & $\$ 0.25$ \\
\hline $\mathrm{CA}$ & $\$ 2.50$ & & & $\$ 2.50$ \\
\hline DE & & $\$ 4.00$ & & $\$ 4.00$ \\
\hline DC & $\$ 2.75$ & & & $\$ 2.75$ \\
\hline $\mathrm{FL}$ & $\$ 4.00$ & & & $\$ 4.00$ \\
\hline $\mathrm{GA}$ & & $\$ 2.60$ & & $\$ 2.60$ \\
\hline $\mathrm{HI}$ & & $\$ 2.80$ & & $\$ 2.80$ \\
\hline ID & & $\$ 3.20$ & & $\$ 3.20$ \\
\hline KY & & $\$ 3.00$ & & $\$ 3.00$ \\
\hline LA & $\$ 3.20$ & & & $\$ 3.20$ \\
\hline ME & & $\$ 0.50$ & & $\$ 0.50$ \\
\hline MD & $\$ 2.50$ & & & $\$ 2.50$ \\
\hline MA & $\$ 4.40$ & $\$ 0.25$ & & $\$ 4.65$ \\
\hline MN & $\$ 2.25$ & & & $\$ 2.25$ \\
\hline MT & & $\$ 0.13$ & & $\$ 0.13$ \\
\hline NV & $\$ 2.10$ & & & $\$ 2.10$ \\
\hline $\mathrm{NH}$ & $\$ 3.00$ & & & $\$ 3.00$ \\
\hline NJ & $\$ 2.00$ & & & $\$ 2.00$ \\
\hline NM & & $\$ 0.80$ & & $\$ 0.80$ \\
\hline NY & $\$ 3.50$ & $\$ 1.25$ & $\$ 1.25$ & $\$ 6.00$ \\
\hline NC & & $\$ 2.80$ & & $\$ 2.80$ \\
\hline ND & & $\$ 1.20$ & & $\$ 1.20$ \\
\hline $\mathrm{OH}$ & & & $\$ 3.00$ & $\$ 3.00$ \\
\hline OR & & $\$ 3.00$ & & $\$ 3.00$ \\
\hline PA & & $\$ 2.25$ & & $\$ 2.25$ \\
\hline $\mathrm{RI}$ & & $\$ 2.00$ & & $\$ 2.00$ \\
\hline $\mathrm{SC}$ & & $\$ 2.00$ & & $\$ 2.00$ \\
\hline UT & & $\$ 2.00$ & & $\$ 2.00$ \\
\hline VT & $\$ 3.50$ & & & $\$ 3.50$ \\
\hline WI & $\$ 2.00$ & $\$ 2.00$ & & $\$ 4.00$ \\
\hline WY & & $\$ 0.75$ & & $\$ 0.75$ \\
\hline AZ / Arizona Public Service Co & $\$ 3.00$ & & & $\$ 3.00$ \\
\hline AZ / Salt River Project & $\$ 3.00$ & & & $\$ 3.00$ \\
\hline AZ / Sulphur Springs Valley E C Inc & $\$ 4.00$ & & & $\$ 4.00$ \\
\hline AZ / Trico Electric Cooperative Inc & $\$ 4.00$ & & & $\$ 4.00$ \\
\hline AZ / Tucson Electric Power Co & $\$ 3.00$ & & & $\$ 3.00$ \\
\hline AZ / UNS Electric, Inc & $\$ 3.00$ & & & $\$ 3.00$ \\
\hline CA / City of Alameda & $\$ 2.60$ & & & $\$ 2.60$ \\
\hline CA / City of Anaheim & $\$ 4.00$ & & & $\$ 4.00$ \\
\hline CA / City of Burbank Water and Power & $\$ 3.50$ & & & $\$ 3.50$ \\
\hline CA / City of Colton & $\$ 4.00$ & & & $\$ 4.00$ \\
\hline CA / City of Glendale & $\$ 4.65$ & & & $\$ 4.65$ \\
\hline CA / City of Lodi & $\$ 2.60$ & & & $\$ 2.60$ \\
\hline CA / City of Palo Alto & $\$ 2.00$ & & & $\$ 2.00$ \\
\hline CA / City of Pasadena & $\$ 3.15$ & & & $\$ 3.15$ \\
\hline CA / City of Redding & $\$ 3.30$ & & & $\$ 3.30$ \\
\hline CA / City of Riverside & $\$ 3.00$ & & & $\$ 3.00$ \\
\hline
\end{tabular}




\begin{tabular}{|c|c|c|}
\hline CA / City of Roseville & $\$ 3.00$ & $\$ 3.00$ \\
\hline CA / Imperial Irrigation District & $\$ 2.60$ & $\$ 2.60$ \\
\hline CA / Los Angeles City of & $\$ 6.00$ & $\$ 6.00$ \\
\hline CA / Modesto Irrigation District & $\$ 2.60$ & $\$ 2.60$ \\
\hline CA / Pacific Gas \& Electric Co & $\$ 2.75$ & $\$ 2.75$ \\
\hline CA / Sacramento Municipal Util Dist & $\$ 2.20$ & $\$ 2.20$ \\
\hline CA / Turlock Irrigation District & $\$ 4.00$ & $\$ 4.00$ \\
\hline $\mathrm{CO} /$ Colorado Springs City of & $\$ 3.75$ & $\$ 3.75$ \\
\hline $\mathrm{CO} /$ Holy Cross Electric Assn, Inc & $\$ 2.00$ & $\$ 2.00$ \\
\hline CO / La Plata Electric Assn, Inc & $\$ 2.00$ & $\$ 2.00$ \\
\hline CO / Public Service Co of Colorado & $\$ 3.50$ & $\$ 3.50$ \\
\hline FL / Gainesville Regional Utilities & $\$ 1.50$ & $\$ 1.50$ \\
\hline GA / Central Georgia El Member Corp & $\$ 0.45$ & $\$ 0.45$ \\
\hline GA / GreyStone Power Corporation & $\$ 0.45$ & $\$ 0.45$ \\
\hline GA / Sawnee Electric Membership Corporation & $\$ 0.30$ & $\$ 0.30$ \\
\hline IN / Jackson County Rural E M C & $\$ 0.45$ & $\$ 0.45$ \\
\hline MA / Chicopee City of & $\$ 2.50$ & $\$ 2.50$ \\
\hline MN / Crow Wing Cooperative Power \& Light Comp & $\$ 2.00$ & $\$ 2.00$ \\
\hline MN / Dakota Electric Association & $\$ 2.00$ & $\$ 2.00$ \\
\hline MN / East Central Energy & $\$ 2.00$ & $\$ 2.00$ \\
\hline MN / Itasca-Mantrap Co-op Electrical Assn & $\$ 2.00$ & $\$ 2.00$ \\
\hline MN / Kandiyohi Power Coop & $\$ 2.00$ & $\$ 2.0$ \\
\hline MN / Lake Country Power & $\$ 2.00$ & $\$ 2.00$ \\
\hline MN / Lake Region Coop Elec Assn & $\$ 2.00$ & $\$ 2.00$ \\
\hline MN / McLeod Cooperative Power Assn & $\$ 2.00$ & $\$ 2.00$ \\
\hline MN / Meeker Coop Light \& Power Assn & $\$ 2.00$ & $\$ 2.00$ \\
\hline MN / Mille Lacs Electric Coop & $\$ 2.00$ & $\$ 2.00$ \\
\hline MN / Minnesota Power Inc & $\$ 2.00$ & $\$ 2.00$ \\
\hline MN / Minnesota Valley Coop L\&P Assn & $\$ 2.00$ & $\$ 2.00$ \\
\hline MN / Minnesota Valley Electric Coop & $\$ 2.00$ & $\$ 2.00$ \\
\hline MN / Runestone Electric Assn & $\$ 2.00$ & $\$ 2.00$ \\
\hline MN / Stearns Cooperative Elec Assn & $\$ 2.00$ & $\$ 2.00$ \\
\hline MN / Steele-Waseca Cooperative Electric & $\$ 2.00$ & $\$ 2.00$ \\
\hline MN / Todd-Wadena Electric Coop & $\$ 2.00$ & $\$ 2.00$ \\
\hline MN / Wright-Hennepin Coop Elec Assn & $\$ 2.00$ & $\$ 2.00$ \\
\hline MO / City of Columbia & $\$ 0.50$ & $\$ 0.50$ \\
\hline MO / Independence City of & $\$ 2.50$ & $\$ 2.50$ \\
\hline MT / NorthWestern Energy LLC & $\$ 1.50$ & $\$ 1.50$ \\
\hline NC / City of Washington & $\$ 2.00$ & $\$ 2.00$ \\
\hline NC / South River Elec Member Corp & $\$ 1.00$ & $\$ 1.00$ \\
\hline NH / New Hampshire Elec Coop Inc & $\$ 3.00$ & $\$ 3.00$ \\
\hline NV / Sierra Pacific Power Co & $\$ 2.60$ & $\$ 2.60$ \\
\hline NY / Long Island Power Authority & $\$ 3.50$ & $\$ 3.5$ \\
\hline $\mathrm{OH}$ / South Central Power Company & $\$ 2.00$ & $\$ 2.00$ \\
\hline OK / Lake Region Electric Coop, Inc & $\$ 2.00$ & $\$ 2.00$ \\
\hline OR / Consumers Power, Inc & $\$ 0.50$ & $\$ 0.50$ \\
\hline OR / Eugene City of & $\$ 2.00$ & $\$ 2.00$ \\
\hline OR / Portland General Electric Company & $\$ 2.25$ & $\$ 2.25$ \\
\hline SD / Black Hills Electric Coop, Inc & $\$ 4.50$ & $\$ 4.50$ \\
\hline SD / Black Hills Power Inc & $\$ 4.50$ & $\$ 4.50$ \\
\hline SD / NorthWestern Energy & $\$ 3.00$ & $\$ 3.00$ \\
\hline TN / Tennessee Valley Electric Coop & $\$ 1.00$ & $\$ 1.0$ \\
\hline TX / Austin Energy & $\$ 3.75$ & $\$ 3.75$ \\
\hline TX / City of Bryan & $\$ 4.00$ & $\$ 4.00$ \\
\hline TX / Farmers Electric Coop, Inc & $\$ 1.00$ & $\$ 1.00$ \\
\hline TX / Guadalupe Valley Elec Coop Inc & $\$ 2.00$ & $\$ 2.00$ \\
\hline
\end{tabular}


TX / San Antonio City of

TX / TXU Energy Retail Co LP

UT / City of St George

UT / PacifiCorp

WA / City of Richland

WA / Orcas Power \& Light Coop

WA / Port Angeles City of

WA / PUD No 1 of Clallam County

WA / PUD No 1 of Franklin County

WA / PUD No 1 of Klickitat County

WA / Snohomish County PUD No 1

WI / Wisconsin Electric Power Co

WI / Wisconsin Public Service Corp
$\$ 3.00$

$\$ 2.46$

$\$ 2.00$

$\$ 2.00$

$\$ 0.50$

$\$ 1.50$

$\$ 0.50$

$\$ 0.50$

$\$ 0.50$

$\$ 0.40$

$\$ 0.50$

$\$ 0.75$

$\$ 3.00$
$\$ 3.00$

$\$ 2.46$

$\$ 2.00$

$\$ 2.00$

$\$ 0.50$

$\$ 1.50$

$\$ 0.50$

$\$ 0.50$

$\$ 0.50$

$\$ 0.40$

$\$ 0.50$

$\$ 0.75$

$\$ 3.00$ 


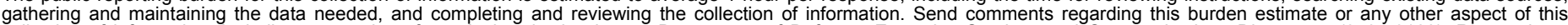

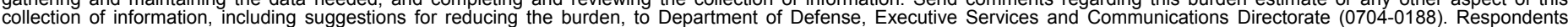

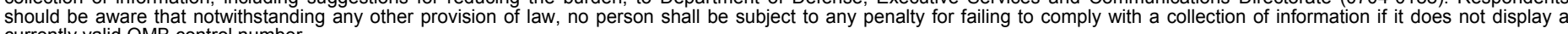

PLEASE DO NOT RETURN YOUR FORM TO THE ABOVE ORGANIZATION.

\begin{tabular}{l|l|l|l} 
1. REPORT DATE (DD-MM-YYYY) & 2. REPORT TYPE & 3. DATES COVERED (FrOm - TO)
\end{tabular}

December 2009

Technical Report

4. TITLE AND SUBTITLE

Break-Even Cost for Residential Photovoltaics in the United States:

Key Drivers and Sensitivities

5a. CONTRACT NUMBER

DE-AC36-08-GO28308

5b. GRANT NUMBER

5c. PROGRAM ELEMENT NUMBER

5d. PROJECT NUMBER

TP-6A2-46909

P. Denholm, R.M. Margolis, S. Ong, and B. Roberts 5e. TASK NUMBER

PVD9.1210

5f. WORK UNIT NUMBER
7. PERFORMING ORGANIZATION NAME(S) AND ADDRESS(ES)

National Renewable Energy Laboratory

1617 Cole Blvd.

Golden, CO 80401-3393

9. SPONSORING/MONITORING AGENCY NAME(S) AND ADDRESS(ES)
8. PERFORMING ORGANIZATION REPORT NUMBER

NREL/TP-6A2-46909

10. SPONSOR/MONITOR'S ACRONYM(S) NREL

11. SPONSORING/MONITORING AGENCY REPORT NUMBER

\section{DISTRIBUTION AVAILABILITY STATEMENT}

National Technical Information Service

U.S. Department of Commerce

5285 Port Royal Road

Springfield, VA 22161

\section{SUPPLEMENTARY NOTES}

\section{ABSTRACT (Maximum 200 Words)}

Grid parity_or break-even cost-for photovoltaic (PV) technology is defined as the point where the cost of PV-generated electricity equals the cost of electricity purchased from the grid. Break-even cost is expressed in $\$ / W$ of an installed system. Achieving break-even cost is a function of many variables. Consequently, break-even costs vary by location and time for a country, such as the United States, with a diverse set of resources, electricity prices, and other variables. In this report, we analyze PV break-even costs for U.S. residential customers. We evaluate some key drivers of grid parity both regionally and over time. We also examine the impact of moving from flat to time-of-use (TOU) rates, and we evaluate individual components of the break-even cost, including effect of rate structure and various incentives. Finally, we examine how PV markets might evolve on a regional basis considering the sensitivity of the break-even cost to four major drivers: technical performance, financing parameters, electricity prices and rates, and policies. We find that local incentives rather than "technical" parameters are in general the key drivers of the break-even cost of PV. Additionally, this analysis provides insight about the potential viability of PV markets.

\section{SUBJECT TERMS}

grid parity; break-even cost; break-even price; break-even point; breakeven; solar energy; solar resource; photovoltaics; PV; PV technology; PV markets; market viability; United States; U.S. utilities; electricity; electricity policies; residential customers; local electricity prices; electricity costs; electricity rates; financing; incentives; technical performance; time-of-use rates; TOU rates; rate structures

\begin{tabular}{|c|c|c|}
\hline $\begin{array}{l}\text { a. REPORT } \\
\text { Unclassified }\end{array}$ & $\begin{array}{l}\text { b. ABSTRACT } \\
\text { Unclassified }\end{array}$ & $\begin{array}{l}\text { c. THIS PAGE } \\
\text { Unclassified }\end{array}$ \\
\hline
\end{tabular}

\begin{tabular}{l|l} 
17. LIMITATION & 18. \\
OF ABSTRACT & OF PAGES \\
UL & \\
& \\
\hline
\end{tabular}

19a. NAME OF RESPONSIBLE PERSON

19b. TELEPHONE NUMBER (Include area code) 